\title{
Exposure Intended Dose Regimen
}

National Cancer Institute

\section{Source}

National Cancer Institute. Exposure Intended Dose Regimen. NCI Thesaurus. Code C83277.

A treatment plan that specifies the amount, schedule and duration of an exposure. 